\title{
Hubungan Kemelimpahan Chlorella sp Dengan Kualitas Lingkungan Perairan Pada Skala Semi Masal di BBBPBAP Jepara
}

\author{
Siska Aprilliyanti1 ${ }^{1}$, Tri Retnaningsih Soeprobowati1,2, Bambang Yulianto ${ }^{1,3}$ \\ ${ }^{1}$ Magister Ilmu Lingkungan Universitas Diponegoro; email: siska prilly@yahoo.com \\ 2Jurusan Biologi FSM Universitas Diponegoro,Program Pasca Sarjana UNDIP \\ ${ }_{3}^{3} J u r u s a n$ Kelautan FPIK Universitas Diponegoro
}

\begin{abstract}
ABSTRAK
Chlorella sp merupakan salah satu mikroalga yang sering dibudidayakan untuk berbagai keperluan seperti obatobatan, kosmetik, atau untuk alternatif biodiesel Chlorella sp merupakan suatu agen bioremediasi yang baik, selain dapat hidup pada lingkungan yang tercemar juga dapat memakai logam berat sebagai logam esensial untuk metabolisme. Banyaknya manfaat yang akan dapat diambil apabila dapat mengembangkan Chlorella sp pada skala masal. Dengan kemanfaatannya dari Chlorella sp maka penulis melakukan penelitian dengan menggunakan Chlorella sp sebagai objeknya. Tujuan dari penelitian ini adalah untuk mengetahui hubungan antara kemelimpahan Chlorella sp dengan kualitas lingkungan perairan di Kabupaten Jepara. Chlorella sp ini dikultivasi di luar ruangan dengan sumber cahaya berasal dari sinar matahari secara langsung, pengudaraan untuk pencampuran media menggunakan blower yang dialirkan melalui selang dan kran aerasi untuk mencampur media. Aerasi dalam penelitian ini digunakan dengan tujuan agar sel Chlorella sp dapat memperoleh nutrisi dalam media kultivasi secara merata karena adanya sirkulasi air dalam wadah kultur (Amini, 2006). Dari hasil analisis data diperoleh nilai koefisien determinasi (R2) = 0,995 . Hal ini memberikan gambaran bahwa terdapat hubungan yang sangat kuat antara variabel bebas yakni kelima parameter kualitas air (nitrat, fosfat, temperature, $\mathrm{pH}$ dan salinitas) dengan variabel terikat yakni kemelimpahan Chlorella sp. Selanjutnya diperoleh persamaan regresi linier berganda sebagai berikut:Y $=-5323.54-16.80$ nitrat 60.78 fosfat + 111.09 temperatur + ; $997.26 \mathrm{pH}-191.92$ salinitas. Dari persamaan regresi tersebut memperlihatkan bahwa parameter kualitas air yang memiliki hubungan searah (berbanding lurus) adalah temperature dan $\mathrm{pH}$. Sedangkan parameter kualitas air yang memiliki hubungan berbanding terbalik yaitu; nitrat,fosfat dan salinitas. Hubungan kemelimpahan Chlorella sp dengan kualitas lingkungan perairan skala semi masal kuat, hasil analisis regresi didapat nilai Adjusted R2 0,995, artinya persentase sumbangan pengaruh variabel nitrat,fosfat,temperature, pH dan salinitas terhadap kemelimpahan Chlorella adalah sebesar 99,5\% dan sisanya dipengaruhi oleh faktor lain. Nilai koefisien / pengaruh tertinggi terdapat pada parameter $\mathrm{pH}$ yaitu $(997,49)$.
\end{abstract}

Kata kunci: Chlorella sp, kualitas lingkungan, semi masal, Jepara

\section{ABSTRACT}

Chlorella sp is one of the microalgae are often cultivated for various purposes such as pharmaceuticals, cosmetics, or for alternative biodiesel Chlorella sp an agent of bioremediation good, but can live in a polluted environment can also wear a heavy metal as the metal essential for metabolism. The many benefits that will be taken if it can develop Chlorella sp on a mass scale. With the emergence of Chlorella sp author conducted research using Chlorella sp as its object. The purpose of this study was to determine the relationship between the abundance of Chlorella sp with the quality of the water environment in the district of Jepara.Chlorella sp is cultivated outdoors with a light source coming from direct sunlight, aeration for mixing media using a blower that flowed through the hose and faucet aeration to mix media. Aeration used in this study with the aim of Chlorella sp cells can obtain nutrients evenly in cultivation media for their water circulation in the culture vessel (Amini, 2006). From the analysis of data obtained by the coefficient of determination $(\mathrm{R} 2)=0.995$. This illustrates that there is a very strong relationship between the independent variables namely the five parameters of water quality (nitrates, phosphates, temperature, $\mathrm{pH}$ and salinity) with the dependent variable abundance of Chlorella sp. Furthermore, multiple linear regression equation as follows: $\mathrm{Y}=-5323.54-16.80-60.78$ nitrate phosphate $+111.09+$ temperature; $997.26-191.92 \mathrm{pH}$ salinity. From the regression equation shows that the water quality parameters that have a unidirectional relationship (proportional) is temperature and $\mathrm{pH}$. While water quality parameters which have an inverse relationship, namely; nitrate, phosphate and salinity. Chlorella sp abundance relationships with water environmental quality semi massive scale strong, the results of the regression analysis obtained Adjusted R2 value of 0.995, meaning that the percentage contribution of variables influence nitrates, phosphates, temperature, $\mathrm{pH}$ and salinity of the abundance of Chlorella is $99.5 \%$ and the rest is influenced by factors other. The coefficient of impact / highest in pH parameters ie (997.49).

Keywords: Chlorella sp, environmental quality, semi-massive, Jepara 
Cara sitasi: Apriliyanti, S., Soeprobowati, T. R., Yulianto, B. (2016). Hubungan Kemelimpahan Chlorella sp dengan Kualitas Lingkungan Perairan pada Skala Semi Masal di BBBPBAP Jepara. Jurnal Ilmu Lingkungan,14(2),77-81, doi:10.14710/jil.14.2.77-81

\section{PENDAHULUAN}

Chlorella sp adalah fitoplankton yang sering dijumpai di perairan umum,baik itu perairan tawar maupun perairan laut (Wigajatri R.P, dkk 2003). Karena tidak beracun, namun memiliki nilai gizi yang tinggi, Chlorella sp merupakan salah satu mikroalga yang sering dibudidayakan untuk berbagai keperluan seperti obat-obatan, kosmetik, atau untuk alternatif biodiesel. Sifat kosmopolitan Chlorella sp mampu hidup di mana-mana kecuali di tempat yang sangat penting bagi kehidupan. Pertumbuhan Chlorella sp yang

dikultur sangat ditentukan oleh ketersediaan nutrien (unsur hara) dan kondisi lingkungan (Sylvester et al. 2002). Faktor pembatas dalam budidaya Chlorella sp adalah nitrat dan fosfat. Beberapa manfaat Chlorella sp diantaranya: (1) berkembangbiak dengan cepat pada kondisi tumbuhnya, (2) mudah dalam membudidayakan, (3) menghasilkan oksigen melalui proses fotosintesis, dan (4) mengandung protein yang tinggi dengan komponen utama asam amino (Nakayama, 1992 dalam Arifin, F, 2012). Selain nutrien dan kondisi lingkungan yang sesuai dengan Chlorella sp, inokulum juga merupakan faktor yang sangat penting di dalam kultur Chlorella spp karena kultur tidak mungkin dilaksanakan tanpa adanya inokulum (Sapta et al. 2002).

Chlorella sp adalah salah satu jenis alga hijau bersel satu. Selnya berdiri sendiri dengan berbentuk bulat atau bulat telur dengan diameter 3 - 8 mikron, memiliki khloroplas berbentuk seperti cawan dan dindingnya keras. Warnanya hijau cerah, hidup dipermukaan air tawar, namun ada juga yang hidup di air asin (Afandi, 2003). Chlorella sp dapat bergerak tetapi sangat lambat sehingga pada pengamatan seakan - akan tidak bergerak. Alga ini dapat tumbuh pada salinitas 0 - 35 ppt. Alga ini masih dapat bertahan hidup pada suhu $40^{\circ} \mathrm{C}$, tetapi tidak tumbuh. Kisaran suhu $25-30^{\circ} \mathrm{C}$ merupakan kisaran suhu yang optimal untuk pertumbuhan alga ini (Isnansetyo \& Kurniastuty, 1995).

Chlorella sp merupakan suatu agen bioremediasi yang baik, selain dapat hidup pada lingkungan yang tercemar juga dapat memakai logam berat sebagai logam esensial untuk metabolisme. Banyaknya manfaat yang akan dapat diambil apabila dapat mengembangkan Chlorella sp pada skala masal. Dengan kemanfaatannya dari Chlorella sp maka penulis melakukan penelitian dengan menggunakan Chlorella sp sebagai objeknya. Tujuan dari penelitian ini adalah untuk mengetahui hubungan antara kemelimpahan Chlorella sp dengan kualitas lingkungan perairan di Kabupaten Jepara.

\section{METODE PENELITIAN}

Dalam penelitian ini alat dan bahan yang dibutuhkan antara lain;

\subsection{Alat dan Bahan}

\subsubsection{Alat}

Alat dibagi atas dua kelompok yaitu alat yang digunakan di lapangan dan alat yang digunakan di laboratorium. Adapun alat dan bahan yang digunakan dalam penelitian ini di sajikan pada Tabel 1 dan 2 . dibawah ini;

Tabel 1. Daftar alat yang digunakan di lapangan

\begin{tabular}{|c|c|c|c|}
\hline No. & Alat & Jumla & Fungsi Alat \\
\hline 1. & $\begin{array}{ll}\text { Ember } & \text { plastic } \\
\text { Volume } 70 \mathrm{~L} & \end{array}$ & $\begin{array}{l}2 \\
0\end{array}$ & $\begin{array}{ll}\text { Wadah } & \text { untuk } \\
\text { penelitian }\end{array}$ \\
\hline 2. & $\begin{array}{l}\text { Blower, Batu dan } \\
\text { selang aerasi }\end{array}$ & 20 & $\begin{array}{l}\text { Penunjang } \\
\text { ketersediaan DO dan } \\
\text { pengadukan nutrien }\end{array}$ \\
\hline 3. & Boto & 20 & Pengambilan sampel \\
\hline 4. & DO $\mathrm{n}$ & 1 & ur $\mathrm{O}_{2}$ terlarut \\
\hline 5. & Termometer & & $\begin{array}{l}\text { Pengukur suhu media } \\
\text { uji }\end{array}$ \\
\hline 6. & $\begin{array}{l}\text { Aplikasi Light-o- } \\
\text { meter di hp android }\end{array}$ & 1 & $\begin{array}{l}\text { Mengukur intensitas } \\
\text { cahaya matahari }\end{array}$ \\
\hline 7. & $\begin{array}{l}\text { pH meter (ketelitian } \\
0,1 \text { ) }\end{array}$ & 1 & Pengukur $\mathrm{pH}$ \\
\hline 8. & pH proff & 1 & an pH tanah \\
\hline 9. & Refraktometer & 1 & Mengukur salinitas \\
\hline 10. & $\begin{array}{l}\text { Alat Tulis, Kamera } \\
\text { Digital }\end{array}$ & 1 & $\begin{array}{l}\text { Mencatat } \\
\text { Dokumentasi }\end{array}$ \\
\hline
\end{tabular}

Tabel 2. Daftar Alat Yang Digunakan Di Laboratorium

\begin{tabular}{|c|c|c|}
\hline No & Alat & Kegunaan \\
\hline 1 & $\begin{array}{l}\text { Sentrifuge Hettich } \\
\text { Universal }\end{array}$ & Mengendapkan kertas saring \\
\hline 2 & Spectronic 21 & $\begin{array}{l}\text { Mengukur biomassa klorofil- } \\
a \text {, nitrat dan fosfat }\end{array}$ \\
\hline 3 & Spatula & $\begin{array}{l}\text { Menghancurkan } \\
\text { saring }\end{array}$ \\
\hline 4 & $\begin{array}{lr}\begin{array}{l}\text { Peralatan } \\
\text { (tabung }\end{array} & \text { Glas } \\
\text { pipet dll) } & \end{array}$ & $\begin{array}{l}\text { Membantu proses analisis } \\
\text { klorofil- } a\end{array}$ \\
\hline
\end{tabular}

\subsubsection{Bahan}

Bahan yang digunakan dalam penelitian ini, tersaji pada tabel 3 dibawah ini;

Tabel 3. Daftar Bahan Yang Digunakan Dilaboratorium

\begin{tabular}{cll}
\hline No & Bahan & Kegunaan \\
\hline 1 & Media Air Payau & Bahan untuk analisis \\
& & klorofil- $a$ \\
2 & Biomass Chlorella & sp \\
3 & Pupuk anorganik & Urea, \\
& Sp-36,NPK & \\
\hline
\end{tabular}


Apriliyanti, S., Soeprobowati, T. R., Yulianto, B. (2016). Hubungan Kemelimpahan Chlorella sp dengan Kualitas Lingkungan Perairan pada Skala Semi Masal di BBBPBAP Jepara. Jurnal IImu Lingkungan,14(2),77-81, doi:10.14710/jil.14.2.77-81

Metode penelitian yang digunakan adalah metode korelasional. Dalam penelitian ini, peneliti berusaha menggambarkan kondisi sekarang dalam konteks kuantitatif yang direfleksikan dalam variabel. Metode ini digunakan untuk meneliti bagaimana hubungan kemelimpahan Chlorella sp dengan kualitas lingkungan perairan di Kabupaten Jepara . Data yang dikumpulkan berupa data kualitas air baik yang diukur dan diamati secara langsung di lapang atau yang dianalisis di laboratorium. Selanjutnya data yang diperoleh ditabulasikan ke dalam bentuk tabel dan grafik. Data parameter kualitas air akan dianalisis secara deskriptif. Sedangkan untuk melihat hubungan antara beberapa parameter kualitas air dengan kelimpahan Chlorella sp dianalisis dengan menggunakan regresi linier berganda.

\subsection{Inokulan dan pemupukan}

Chlorella sp yang digunakan sebagai inokulan berasal dari laboratorium pakan alami skala masal di BBBPAP Jepara dan dikultivasi dengan pupuk 80 ppm urea, 40 ppm SP-36, ZA 60 ppm, 1 ppm NPK dan 5 ppm EDTA.

\subsection{Kultivasi Chlorella sp}

Media air laut diambil dari perairan sekitar BBPBAP Jepara. Untuk menghindari kontaminasi yang terbawa oleh air laut dilakukan sterilisasi. Sterilisasi dimulai dengan penyaringan terlebih dahulu untuk membersihkan air laut dari partikel partikel kecil dan pengotor lainnya. Air yang telah disaring diberi khlorin sesuai dengan volume yang dibutuhkan. Pemberian khlorin dengan konsentrasi 30 ppm selama 24 jam. Setelah netral air medianya, pupuk 80 ppm urea, 40 ppm SP-36, ZA 60 ppm, 1 ppm NPK dan 5 ppm EDTA dimasukan kedalam media kultur diikuti dengan pemberian inokulan sebanyak $10 \times 10^{4} \mathrm{sel} / \mathrm{ml}$. Chlorella ini dikultivasi di luar ruangan dengan sumber cahaya berasal dari sinar matahari secara langsung, pengudaraan untuk pencampuran media menggunakan blower yang dialirkan melalui selang dan kran aerasi untuk mencampur media. Aerasi dalam penelitian ini digunakan dengan tujuan agar sel Chlorella sp dapat memperoleh nutrisi dalam media kultivasi secara merata karena adanya sirkulasi air dalam wadah kultur (Amini, 2006).

\subsection{Pengukuran pertumbuhan}

Pertumbuhan Chlorella sp dihitung dengan mengukur kepadatan sel. Kepadatan sel ditentukan dengan menggunakan hemasitometer Neabauer. Pengamatan dilakukan dibawah mikroskop cahaya dengan perbesaran 40 kali (Isnansetyo dan Kurniastuty, 1995)

\subsection{Analisis Data}

Data fisika dan kimia perairan dianalisis secara deskriptif. Sedangkan hubungan beberapa parameter kualitas air dengan kemelimpahan Chlorella sp dianalisis secara statistik dengan menggunakan regresi linear berganda (Sudjana, 1992).

$\mathrm{Y}=\mathrm{a}+\mathrm{b}_{1} \mathrm{X}_{1}+\mathrm{b}_{2} \mathrm{X}_{2}+\mathrm{b}_{3} \mathrm{X}_{3}+\mathrm{b}_{4} \mathrm{X}_{4}+\mathrm{b}_{5} \mathrm{X}_{5}$

dimana :

$\mathrm{Y}=$ Kemelimpahan Chlorella sp (sel $/ \mathrm{ml})$

$\mathrm{a}$ dan $\mathrm{b}=$ konstanta

$\mathrm{X}_{1}=$ Nitrat; $\mathrm{X}_{2}=$ Fosfat, $\mathrm{X}_{3}=$ Temperatur, $\mathrm{X}_{4}=\mathrm{pH}$ dan $\mathrm{X}_{5}$ adalah salinitas

\section{HASIL DAN PEMBAHASAN}

Penelitian ini dilaksanakan pada tanggal 18 juni 2015 sampai dengan 1 juli 2015. Lokasi penelitian di area kultur massal Chlorella sp Laboratorium pakan alami Balai Besar Perikanan Air Payau Jepara, Lokasi penelitian dengan google map dapat dilihat pada Gambar 1 di bawah ini;

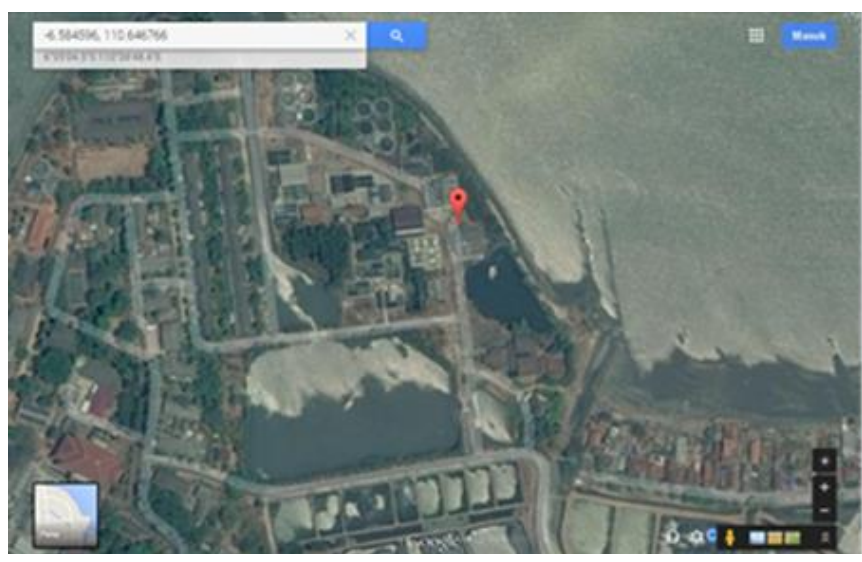

Gambar 1. Lokasi penelitian

\subsection{Kemelimpahan Chlorella sp}

Berdasarkan hasil perhitungan kemelimpahan Chlorella sp yang dilakukan dua hari sekali di dapat hasil rata - rata kemelimpahan seperti yang terlihat pada gambar 2 di bawah ini.

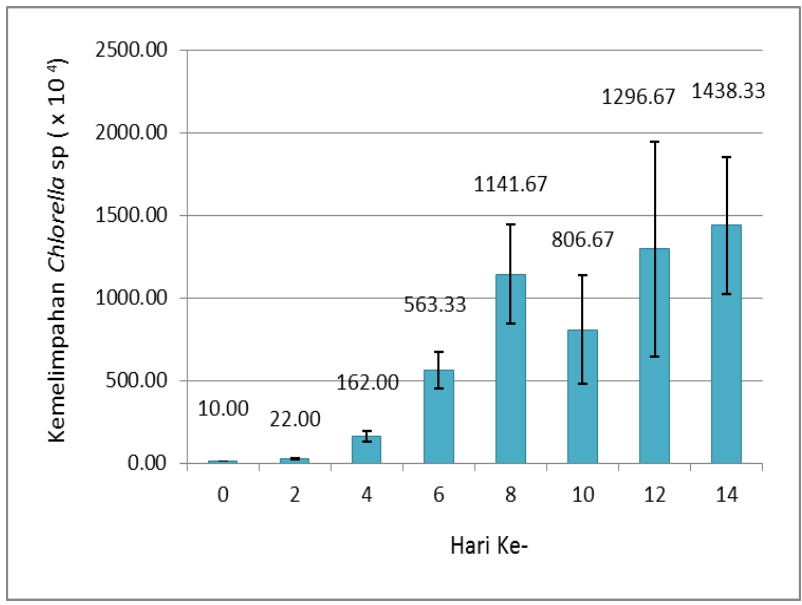

Gambar 2. Grafik rata-rata kemelimpahan Chlorella sp selama pengamatan 
Dari hasil pengamatan Kemelimpahan Chlorella sp selama penelitian, kemelimpahan Chlorella sp tertinggi terjadi pada hari ke 14, dengan jumlah kemelimpahan adalah $14,83 \times 10^{6} \mathrm{sel} / \mathrm{ml}$, hasil kemelimpahan ini lebih rendah dari hasil penelitian yang dilakukan (Tetelepta, 2011), dengan inokulan 10 x $10^{4}$, kemelimpahan Chlorella sp tertinggi mencapai $92,1 \times 10^{7}$, hal ini karena kultivasi pada penelitian ini dilakukan pada ruang terbuka dengan sumber cahaya berasal dari sinar matahari langsung, sedangkan pada penelitian yang dilakukan (Tetelepta, 2011) penelitian dilakukan di dalam laboratorium, dengan cahaya lampu sebagai sumber cahaya selama 24 jam, sehingga kondisi lingkungannya lebih stabil selain itu dengan penggunaan pupuk walne, sehingga nutrisi yang menunjang kemelimpahan Chlorella sp lebih tinggi. Namun dengan peggunaan pupuk teknis yang sama yang dilakukan oleh Amini 2006, kemelimpahan Chlorella sp pada penelitian ini lebih tinggi. Penelitian yang dilakukan Amini 2006 kemelimpahan Chlorella sp adalah 10,79 x $106 \mathrm{sel} / \mathrm{ml}$, hal ini menunjukkan Chlorella sp dapat dikultivasi pada skala semi masal dengan hasil biomassa yang lebih tinggi dengan kultivasi di dalam laboratorium dengan penggunaan pupuk teknis yang sama.

\subsection{Kualitas Lingkungan perairan}

Hasil analisis kualitas lingkungan perairan yang berkorelasi dengan kemelimpahan Chlorella sp skala semi masal di BBPBAP Jepara disajikan dalam Tabel 1.

Tabel 1. Kisaran rata-rata kualitas lingkungan perairan pada penelitian ini.

\begin{tabular}{|c|c|c|}
\hline Parameter & Kisaran Rata - Rata & Kelayakan \\
\hline Nitrat & $0.60-6.66 \pm 2,19$ & $\begin{array}{l}0,9-3,5 \\
\text { (Mackentum)(19 } \\
69)\end{array}$ \\
\hline Fosfat & $0.72-2.88 \pm 0,24$ & $\begin{array}{l}0.09-1.80 \\
\text { (Mackentum } \\
\text { )(1969) }\end{array}$ \\
\hline Temperatur & $31.33-33.77 \pm 0,37$ & $\begin{array}{l}25-30 \text { (Aksu dkk } \\
1992)\end{array}$ \\
\hline Salinitas & $32.33-36.33 \pm 1,57$ & $\begin{array}{l}15-35 \text { ppt (Hirata, } \\
1981 \text { dalam } \\
\text { Rostini, 2007), }\end{array}$ \\
\hline $\mathrm{pH}$ & $9.82 \pm 0,20$ & $\begin{array}{l}8-11 \\
2006)\end{array}$ \\
\hline
\end{tabular}

\subsubsection{Nitrat}

Kandungan nitrat pada perlakuan berkisar antara 0,0646 - 6,66 mg/l, hal ini masih dalam kondisi optimum bagi pertumbuhan Chlorella sp, karena Chlorella sp memerlukan kandungan nitrat pada kisaran 0.9-3.5 mg/l (Mackentum 1969),

\subsubsection{Fosfat}

Kandungan fosfat pada perlakuan ini berkisar antara 0.72 - 2.88 , hal ini masih dalam kisaran optimum untuk pertumbuhan Chlorella sp, karena menurut Sumardianto (1995) bahwa kandungan 80 ortofosfat yang optimal bagi pertumbuhan fitoplankton adalah 0.27-5.51 $\mathrm{mg} / \mathrm{l}$, dan jika kandungannya kurang dari $0.02 \mathrm{mg} / \mathrm{l}$ maka akan menjadi faktor pembatas. Pada kadar di bawah 0,1 ppm atau di atas 45 ppm, nitrat dapat merupakan faktor pembatas kesuburan (Lapu,1994).

\subsection{3. $\mathrm{pH}$}

Nilai rata-rata $\mathrm{pH}$ selama penelitian berkisar antara 8.25 - 9.82, dan ini merupakan batas yang optimum untuk pertumbuhan Chlorella sp karena menurut Amini,dkk (2006) pertumbuhan optimum Chlorella sp pada pH antara 8,0 - 11.00.

\subsubsection{Temperatur}

Temparatur media kultur pada penelitian ini berada pada kisaran 31.33 - $33.77{ }^{\circ} \mathrm{C}$, yang artinya masih dalam kisaran optimum bagi sel Chlorella sp, Chlorella air laut dapat tumbuh baik pada salinitas 1535 ppt (Hirata, 1981 dalam Rostini, 2007),

\subsubsection{Salinitas.}

Pada penelitian ini kadar salinitas adalah 32.33 - 36.33 ppt, rella air laut dapat tumbuh baik pada salinitas 15-35 ppt (Hirata, 1981 dalam Rostini, 2007), (Isnansetyo dan Kurniastuty, 1995). Pada penelitian ini media kultur sangat mudah mengalami kenaikan salinitas. Hal ini karena faktor metabolisme selnya sendiri yang mampu mengeksresikan garamgaraman dan juga faktor penguapan yang tinggi terhadap media kultur karena faktor pemanasan cahaya langsung dari sinar matahari yang digunakan sebagai sumber cahaya. Garam - garam terlihat di sekitar wadah penelitian sebagai butiran-butiran putih, terutama pada perlakuan D. Aerasi juga mempercepat terjadinya transpirasi sehingga meningkatkan salinitas pula. Penambahan air tawar dilakukan untuk menurunkan kadar salinitas hingga mendekati kisaran 35 ppt. Nilai salinitas rata-rata berkisar 32-32,5 0/00, secara umum kisaran salinitas di perairan ini masih tergolong alami untuk kehidupan biota air.

\subsection{Hubungan Kemelimpahan Chlorella sp Dengan Kualitas Lingkungan Perairan Pada Skala Semi Masal Di Bbbpbap Jepara.}

Berdasarkan hasil regresi linear berganda tersebut dapat diketahui seberapa besar pengaruh masing-masing variabel bebas terhadap klorofil-a pada fitoplankton dalam bentuk angka kuantitatif statistik. Khusus untuk parameter yang memiliki pengaruh secara nyata terhadap Dari hasil analisis data diperoleh nilai koefisien determinasi (R2) = 0,995 . Hal ini memberikan gambaran bahwa terdapat hubungan yang sangat kuat antara variabel bebas yakni kelima parameter kualitas air (nitrat, fosfat, temperature, $\mathrm{pH}$ dan salinitas) dengan variabel terikat yakni kemelimpahan Chlorella sp. Selanjutnya diperoleh persamaan regresi linier berganda sebagai berikut: 
$\mathrm{Y}=-5323.54-16.80$ nitrat -60.78 fosfat +111.09 temperatur $+997.26 \mathrm{pH}-191.92$ salinitas.

Dari persamaan regresi tersebut memperlihatkan bahwa parameter kualitas air yang memiliki hubungan searah (berbanding lurus) adalah temperature dan $\mathrm{pH}$. Sedangkan parameter kualitas air yang memiliki hubungan berbanding terbalik yaitu; nitrat,fosfat dan salinitas. Hubungan kemelimpahan Chlorella sp dengan kualitas lingkungan perairan skala semi masal kuat, hasil analisis regresi didapat nilai Adjusted $R^{2}$ 0,995, artinya persentase sumbangan pengaruh variabel nitrat ,fosfat,temperature, $\mathrm{pH}$ dan salinitas terhadap kemelimpahan Chlorella adalah sebesar 99,5\% dan sisanya dipengaruhi oleh faktor lain. Nilai koefisien / pengaruh tertinggi terdapat pada parameter $\mathrm{pH}$ yaitu $(997,49)$.

\section{KESIMPULAN}

Kemelimpahan Chlorella sp mempunyai hubungan yang kuat dengan parameter kualitas lingkungan perairan pada skala semi masal, dengan koofisien /pengaruh tertinggi terdapat pada parameter pH yaitu 997,49.

\section{UCAPAN TERIMAKASIH}

Terima kasih diucapkan kepada seluruh keluarga besar Magister Ilmu Lingkungan, yang telah memberikan ilmu tentang lingkungan kepada penulis, kepada Biro Pusdik KKP selaku penyandang dana yang telah memberikan beasiswa kepada penulis , kepada Kepala Balai Besar Perikanan Air Payau dan staf yang telah memberikan ijin dan bantuannya dalam pelaksanaan penelitian, dan juga tak lupa kami ucapkan terima kasih kepada teman - teman MIL angkatan 39 yang selalu memberikan support kepada penulis.

\section{DAFTAR PUSTAKA}

Afandi, Y.V., 2003, Uji Penurunan Kandungan Nitrat dan Fosfat oleh Alga Hijau (Chlorella sp) secara Kontinyu Jurusan Teknik Lingkungan ITS, Surabaya.

Aksu, Z., Y. Sag dan T. Kutsal..1992.The Biosorption of Copper by C. vulgaris and Z. ramigera. Environ Technol. 13 ;579-586

Amini, S. dan Syamdidi., 2006. Konsentrasi Unsur Hara Pada Media Dan Pertumbuhan Chlorella vulgaris Dengan Pupuk Anorganik Teknis Dan Analis. Jurnal Perikananan. (Jurnal Fisheris Science) Volume .VIII Hal. 201-206.

Arifin, F., 2012. 'Uji Kemampuan Chlorella sp Sebagai Bioremidiator Limbah Cair Tahu. Tesis. Universitas Islam Negri MalangMandira). Tesis. MSDP UNDIP

Isnansetyo, A.,Kurniastuty, 1995. Teknik Kultur Phytoplankton dan Zooplankton. Kanisius, Yogyakarta.

Milero, F.J. and M.L. Sohn. 1992. Chemical Oceanography. CRC Press Inc. London. 531 pp.

Sapta AIM, Rusyani E, Erawati L. 2002. Budidaya fitoplankton skala laboratorium. Budidaya Fitoplankton \& Zooplankton 10:4956

Sudjana. 1992. Metode Statistika. Edisi kelima. Bandung : Tarsito

Sumardianto. 1995. Struktur Komunitas Fitoplankton di Perairan Teluk Pelabuhan Ratu. Fakultas Perikanan. IPB
Sutomo. 2005. Kultur tiga jenis mikroalaga (Tetraselmis sp, Chlorella sp, dan Chaetoceros gracilis) dan pengaruh kepadatan awal terhadap pertumbuhan C. gracilis di laboratorium. Oseanologi dan Limnologi di Indonesia 37:4358

Sylvester B, Nelvy D, Sudjiharno. 2002. Persyaratan budidaya fitoplankton. Budidaya Fitoplankton \& Zooplankton 10:2436

Tetelepta, L. (2011). Pertumbuhan Kultur Chlorella spp Skala Laboratorium Pada Beberapa Tingkat Kepadatan . Jurnal Pengembangan Pulau-Pulau Kecil 2011 - ISBN, (978-60298439-2-7), Halaman 198-202.

Wigajatri R.P, Handojo, A., Kurniawan, H., \& Prihantini, N. B. (2003). Studi Karakteristik Fluoresensi Chlorella $\mathrm{Sp}$ : Pengaruh $\mathrm{pH}$ Terhadap Pengkulturan. Jurnal MAKARA, TEKNOLOGI, VOL. 7, NO. 2, Agustus 2003 STUDI, 7(2), 83-88 